\title{
Risk factors and molecular entities of the etiopathogenesis of the knee osteoarthritis (literature review)
}

\author{
V.B. Novakov, O.N. Novakova, M.I. Churnosov \\ Belgorod State National Research University, Belgorod, Russian Federation
}

\begin{abstract}
Introduction Osteoarthritis (OA) is a heterogenic group of disorders of different etiology with similar biological, morphological and clinical manifestations and outcomes. OA is now considered a disease of the whole joint, including alterations in the articular cartilage, subchondral bone, synovial membrane, ligaments, capsule and periarticular muscles. OA of the knee as the most commonly affected joint accounts for the great medical, medical, social and economic impact. Material and methods A literature review assessing Russian and foreign studies on molecular mechanisms of etiology and pathogenesis of knee OA identified a set of factors for which there was consistent evidence for their association with onset of knee OA. A search of studies published in Russian and in English for the last ten years was conducted using bibliographic databases, including PubMed, PubMedCentral, GoogleScholar, eLIBRARY. Search terms included 'knee osteoarthritis', 'etiology', 'pathogenesis', 'risk factors'. Results Review of the literature showed that patients with knee OA are characterized by changes in cartilage, subchondral bone, synovium, suggesting common mechanisms of joint degeneration during OA development. Osteoarthritis (OA) is multifactorial in origin and closely associated with a wide spectrum of local (previous injury, muscle weakness, knee malalignment, knee surgeries, abnormal mechanical loading, excessive high impact sports, occupational physical activities) and systemic risk factors (advanced age, female sex, height, greater body mass index and obesity, hormone status, family history, mineral bone density, vitamin D deficiency, ethnicity). The prevalence of the knee $\mathrm{OA}$ and patterns of joint involvement vary among different racial and ethnic groups. Conclusion The literature review allowed us to identify the molecular mechanisms of etiopathogenesis of knee OA and the major risk factors for the pathology. Keywords: knee osteoarthritis, etiology, pathogenesis, risk factors
\end{abstract}

\section{INTRODUCTION}

Osteoarthritis (OA) is a heterogenic group of disorders of different etiology with similar biological, morphological and clinical manifestations and outcomes. OA is now considered a disease of the whole joint, including alterations in the articular cartilage, subchondral bone, synovial membrane, ligaments, capsule and periarticular muscles [1]. OA of the knee as the most commonly affected joint accounts for the great medical, medical, social and economic impact [2]. The World Health Organization estimates are that $9.6 \%$ of men and $18.0 \%$ of women $>60$ years of age have symptomatic OA. [3]. Radiological signs of OA are normally observed in the population over 65 years old. Knee OA is the most common form of osteoarthritis [4]. Among the adult population of Russia, rheumatoid patients include mostly OA cases with more than 4 million registered in 2012-2013, and more than half of them (about 2.5 million) are individuals older than the working age [5]. Eighty percent of patients with
OA have limitations in movement and $25 \%$ cannot perform their major daily activities [3]. Knee OA leads to a significant decrease in working capacity and disability of people of working age [2]. It should also be noted that patients with progressive OA of the knee joint are at risk of total knee replacement (TKR) which is an effective method of treatment but rather expensive $[6,7]$. Patients $<55$ years of age represent the fastest growing group of TKR recipients according to the joint replacement registry of the R.R. Vreden RNIITO [8]. With the great medical, social and economic impact of the condition, the underlying mechanisms associating knee OA onset, progression and risk factors are not yet understood, but their identification would provide novel targets for the management and prevention of the disease in adults. The review is aimed at the analysis of the Russian and foreign publications on the etiology and pathogenesis of knee OA, as well as the major risk factors for the disease.

\section{MATERIAL AND METHODS}

A literature review assessing Russian and foreign studies on molecular mechanisms of etiology and pathogenesis of knee OA identified a set of factors for which there was consistent evidence for their association with onset of knee OA. A search of studies published in Russian and in English for the last ten years was conducted using bibliographic databases, including PubMed, PubMedCentral, GoogleScholar, eLIBRARY. 
Search terms included 'knee osteoarthritis', 'etiology', 'pathogenesis', 'risk factors'. Earlier papers describing important aspects of etiology and pathogenesis of knee OA, risk factors for the condition were added, if needed.

\section{RESULTS AND DISCUSSION}

Molecular mechanisms of etiology and pathogenesis of knee OA have been explored by international and Russian researchers for many decades [9-22]. It should be noted that in recent years, the understanding of the etiopathogenesis of OA of the knee joint has undergone significant changes. Knowledge about the pathogenesis of the disease has evolved from being presented as agerelated wear and tear of the joint to recognizing the involvement of all the structures into the pathological process, immune and genetic aspects of the disease, and neurogenic mechanisms of pain [9-11]. There are strong associations of the condition with disorders in the metabolism of articular cartilage and subchondral bone in addition to synovial inflammation [11-14]. T.P. Andriacchi et al. (2015) reported the role of biological, mechanical and structural factors in the pathogenesis of OA in the systematic review [15]. The authors noted that a failure in one of the factors (for example, mechanical) led to changes in other factors (for example, biological and/or structural) with resultant destruction of articular cartilage and the development of OA [15]. S. Glyn-Jones et al. (2015) described OA as a multifactorial disease with genetic, biological and biomechanical factors playing an important role in the pathogenesis of the disease [13]. A.I. Dyadyk et al. (2012) presented OA pathogenesis as shown in the diagram [16] (Fig. 1). Articular cartilage degradation and synovial inflammation were seen as major factors in the development of the disease. Cartilage degradation leads to the synthesis of proinflammatory cytokines, "defective" collagens and proteoglycans by chondrocytes, sclerosis, micro-fractures and cysts in the subchondral bone, osteophytes, softening, fissuring and loss of hydrophilicity of the cartilage tissue. Synovial inflammation contributes to joint dysfunction, pain and progression of cartilage degradation.

It should be noted that the inflammatory process affects almost all structures of the joint with resultant synovitis, chondritis, osteitis [11, 17-18]. A longterm chronic inflammatory process in the synovial membrane results in changes in the metabolism of chondrocytes and impaired biosynthetic balance with catabolism prevailing over anabolism [19].

A role of cytokines in the pathogenesis of knee $\mathrm{OA}$ is reported by many researchers [16, 20-22]. It is worth noting that the synthesis of cytokines is dependent on the duration and severity of OA, can change significantly with evident immune response involved in the inflammatory process.

Among cytokines, the most important are interleukin $1 \beta$, tumor necrosis factor $\alpha$, interleukins $6,15,17$ and 18, with increased levels in the synovium, the fluid, and cartilage seen in OA patients [21]. These cytokines lead to increased synthesis of metalloproteinases (MMP) in chondrocytes, decreased synthesis of proteoglycans, tissue inhibitor of MMP contributing to producton of oxygen radicals, nitric oxide with the latter facilitating progression of catabolism in cartilage [22-23].

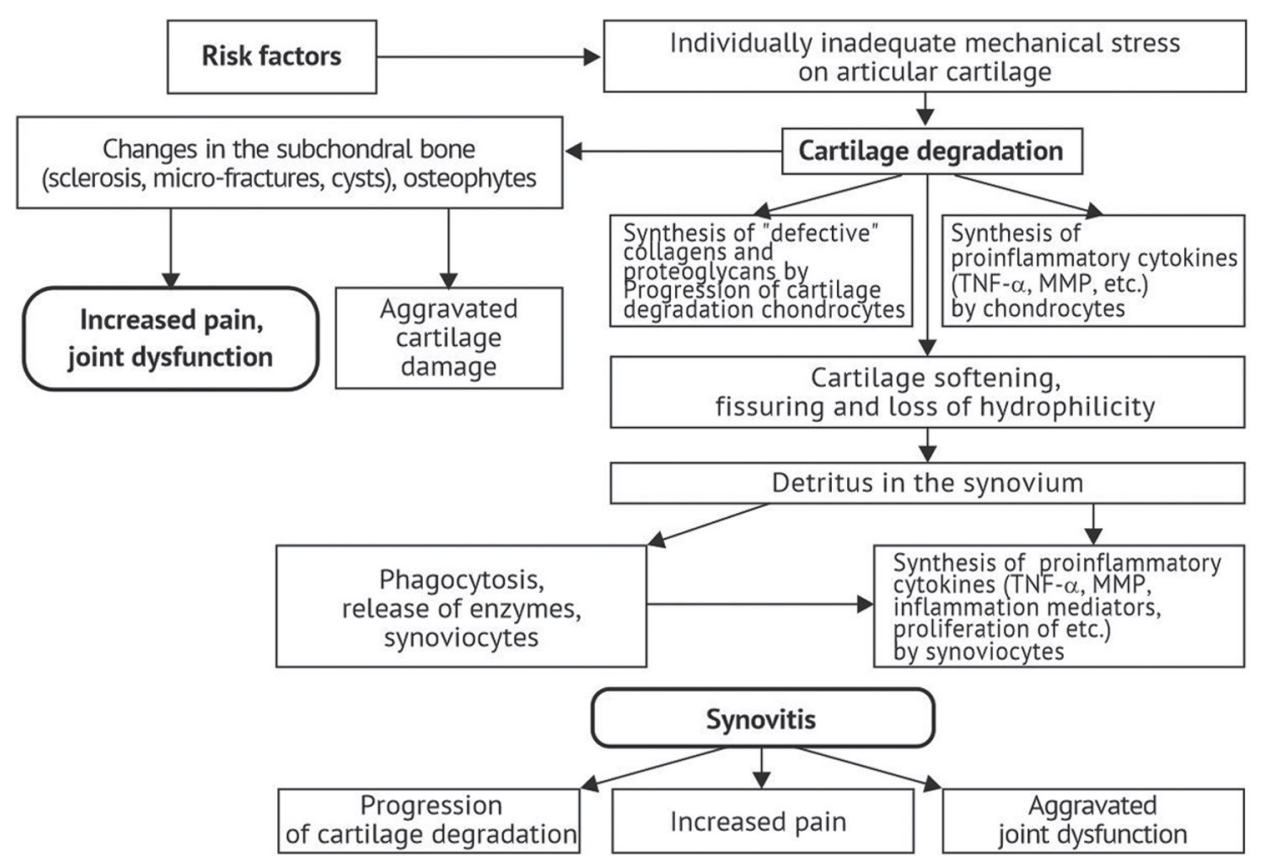

Fig. 1 Diagram of OA pathogenesis [16]. TNF- $\alpha$, tumor necrosis factor $\alpha$, IL-1, interleukin 1, MMP, matrix metalloproteinases 
Destructive changes in the joints in OA are also associated with increased expression of isoform of nitric oxide synthase (NOS). This enzyme is capable of regulating interleukin 1 induced formation of nitric oxide. An increased level of nitric oxide results in chondrocyte resistance to growth factors with the synthesis in the cartilage matrix being suppressed and apoptosis of chondrocytes induced [12].

L.T. Nguyen et al. (2017) presented molecular mechanism of $\mathrm{OA}$ pathogenesis in the form of sequential and interrelated links (Fig. 2) [24]. The first stage was characterized by proteolytic destruction of the cartilage matrix resulting from impaired metabolism of chondrocytes, increased secretion of such degradative enzymes as collagenases and aggrecanases. The second stage involved fibrillation and erosion of the cartilage surface, followed by release of debris products into synovial fluid. At the third stage, inflammation of the synovial membrane resulted from the debris penetrating into synovial cells that facilitated production of proinflammatory cytokines and proteases leading to destruction of the cartilage matrix [24].

G. Musumeci et al. (2015) reported the OAassociated molecules, including IL- $1 \beta$, TNF- $\alpha$, RAGE, leptin, IGF-1, TGF 1 , iNOS, MMP13, laminin, fibronectin, integrin and collagen as being involved in chondrocyte activation contributing to the pathogenesis of OA by destroying the cartilage in the joints or serving as the substrates for extracellular matrix destruction [25]. There are a number of other inflammatory mediators that also contribute to OA pathogenesis.
The biological activity of prostoglandins, leukotrienes, protease-activated receptors (PARs) is known to play a role in tissue degradation and reparation, angiogenesis, nociception, and neurogenic inflammation [26]. Immune factors play a significant role in the pathogenesis of knee OA. Circulating autoantibodies to proteinglycans are detected in the blood of patients with early OA [27]. The resulting antigen-antibody complex leads to the destruction of macrophages in the synovial membrane facilitating release of inflammatory mediators with a damaging effect on chondrocytes and causing synovitis [26]. Meanwhile, the synovial membrane releases biological mediators of inflammation that contribute to destructive processes in the cartilage forming a vicious circle $[17,28]$.

In recent years, views on causal aspects in OA pathogenesis have undergone significant changes. In the first instance, there was cartilage damage, which also affected articular space and subchondral bone at a secondary phase [24]. To date, there is evidence of subchondral bone changes playing a key role in the disease pathogenesis $[18,20]$. Normal bone structure is ensured by a balance between bone formation and resorption. Many hormones, growth factors, and cytokines are involved in the regulation of these processes. According to modern literature $[29,30]$, a key role in the regulation of bone cell metabolism is assigned to the molecular triad: osteoprotegerin; receptor activating transcription factor NFkB; ligand of this receptor (OPG/RANK/ RANKL). The level of sex hormones is one of the factors that regulates functioning of this triad [20].

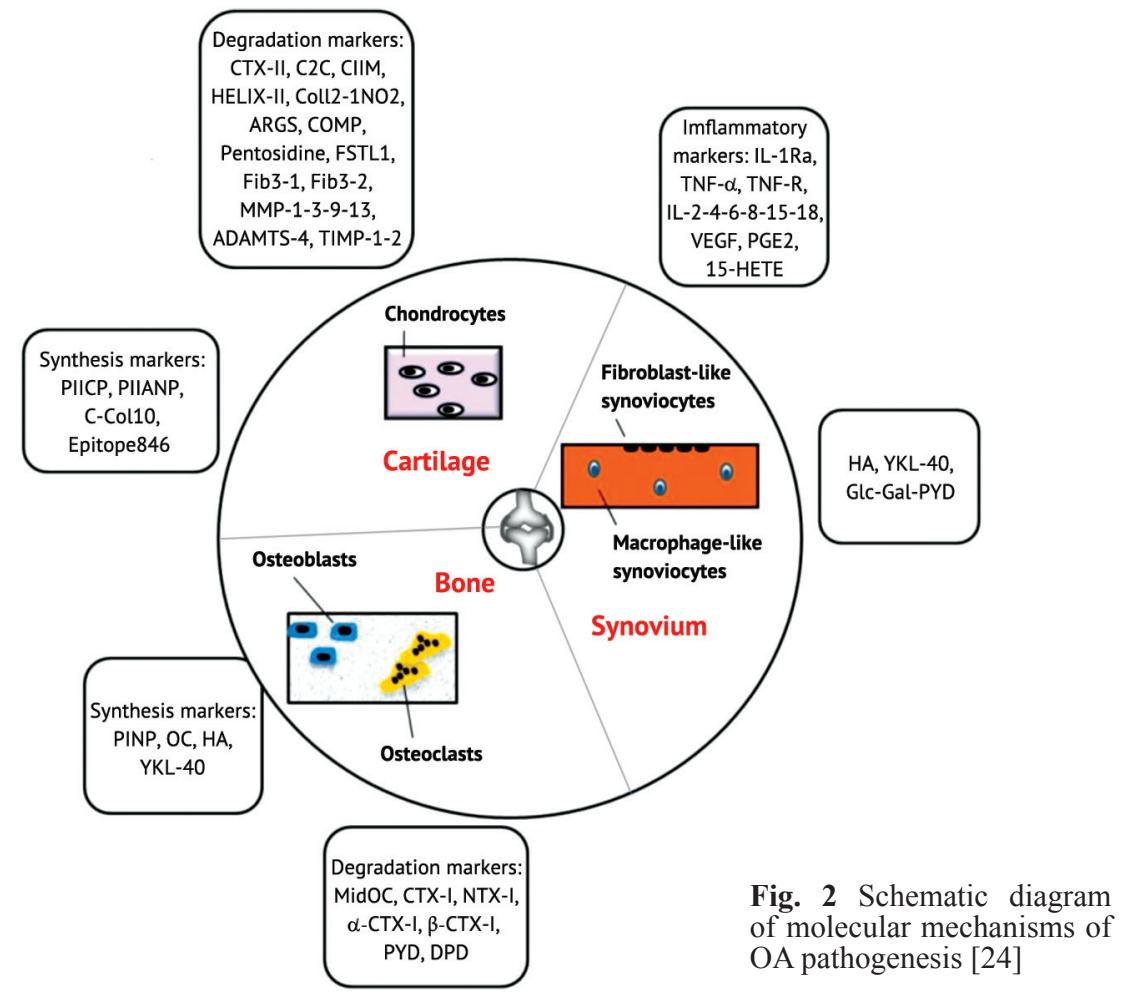


Deficiency of female sex hormones is known to lead to an increase in the expression of RANKL by stromal cells. RANKL binding to RANK, which is expressed on osteoclast progenitors stimulates their differentiation and functional activity of mature cells [19]. At the same time, there is a decrease in RANK - OPG antagonist expression in stromal cells and osteoblasts [29]. These processes lead to changes in the subchondral bone, slowing down bone formation with resultant decrease in the proliferation of osteoblasts and their functional activity.

O.V. Sinyachenko et al. (2016) reported a role of bone metabolism in the pathogenesis of gonarthrosis in patients with knee OA showing significant changes in blood markers of bone metabolism with imbalance of osteoassociated macronutrients (calcium, magnesium, phosphorus), the development of hypocalcemia observed in $98 \%$, high activity of alkaline phosphatase (in $47 \%$ of cases), signs of hyperparathyroidism and hyperosteocalcemia [31]. The main etiological factors of knee OA include micro-and macro-injuries to the joint that occur as a result of intense physical stress including sports, overweight, etc. [17, 22]. In this case, the unevenly distributed load on the surface of the articular cartilage and the maximum pressure are concentrated over a small area, at the site of the greatest convergence of the articular surfaces, leading to cartilage dystrophy and degeneration [12, 32]. These negative processes are associated with impaired cartilage metabolism and decreased level of proteoglycans and collagen fiber tears.

There is evidence of a role of cartilage erosion in the medial knee in OA pathogenesis [33, 34]. S. R. Lyu et al. (2015) revealed higher concentrations of total protein, TNF- $\alpha$, IL- $1 \beta$ and MMP- 3 in the medial part of the knee joint in patients with the disease [33]. A. Heijink et al. (2012) focused on biomechanical aspects of pathogenesis of knee OA including meniscal damage, cartilage defects and joint instability [35].

Osteoarthritis of the knee joint is a multifactorial disease [36]. There are a number of risk factors for the development of knee OA [22, 37, 38]. The current understanding of the origin of $\mathrm{OA}$ is that this disease occurs due to the interaction of many local and systemic risk factors [25, 38, 39]. Systemic risk factors for knee OA include older age, female gender, tall height, overweight and obesity, hormonal status, hereditary predisposition, bone mineral density, vitamin D deficiency, and ethnicity [23, 25, 39, 40]. Local risk factors for OA are history of joint injury, muscle weakness, limb malalignment, surgical interventions on the joint, strenuous physical activity including sports and occupational activity [25, 40-41]. Risk factors such as age, gender, ethnicity, and genetic factors are classified as non-modifiable risk factors for the disease (Fig. 3) [25], and overweight, squatting, and cycling are included in the group of modifiable risk factors for knee OA [42]. G. Musumeci et al. (2015) emphasized the role of local risk factors in the development of OA (Fig. 3).

Age is one of the most important risk factors for knee OA [10, 22, 43]. The prevalence of knee OA increases indefinitely with age [2, 19,44]. Aging can be associated with a decreased ability of chondrocytes to restore the articular cartilage matrix which inevitably leads to a deficiency of interstitial matter. The cartilage matrix is likely to be more sensitive to micro-damage in old age with cell repairation mechanisms failing to compensate for this increasing sensitivity.

Female sex is an important risk factor for knee $\mathrm{OA}$. There is a higher incidence of knee joint OA in women than in men $[19,38]$. Moreover, the risk of knee OA in menopausal women is higher [25] and associated with estradiol deficiency. Sex hormones are known to modify the metabolism of cartilage tissue $[19,20]$. A reduced level of estrogen in menopausal women causes an increased level of metabolism in the subchondral bone, decreased muscle strength and mass and chondrocyte destruction. Hormone replacement therapy with estrogens in postmenopausal women is associated with a lower risk of knee and hip OA [45].

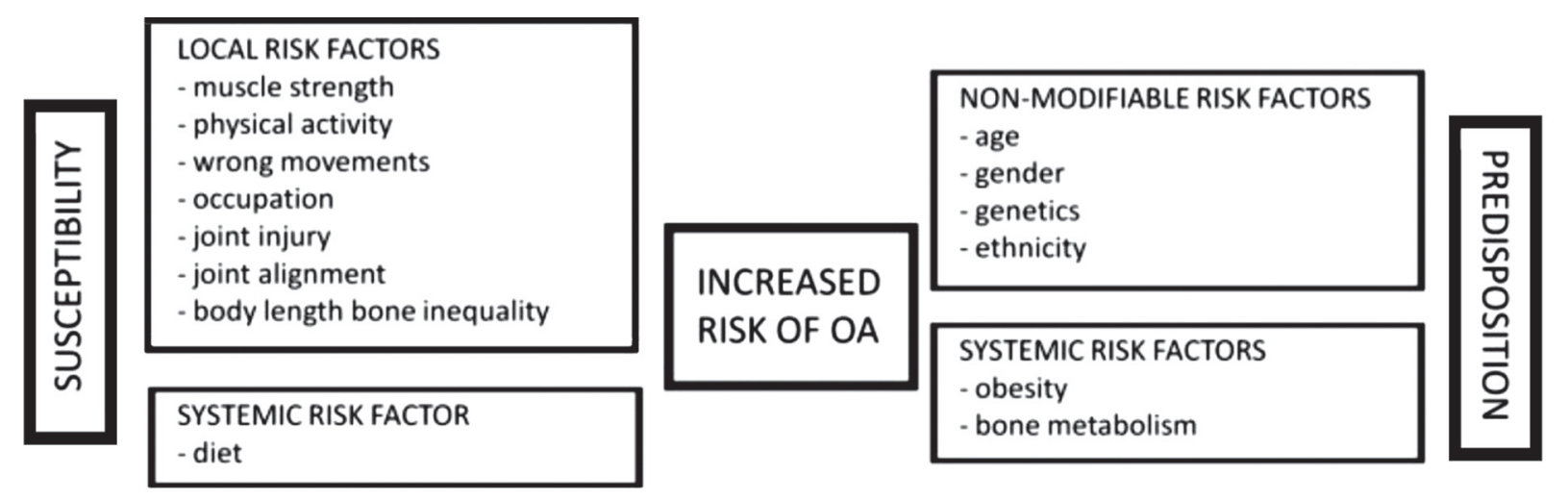

Fig. 3 Schematic diagram of risk factors for OA [25] 
S. Lee et al. (2017) estimated the national prevalence of knee OA in the Korean population and found the condition being 2.1 times higher in women than in men (43.8\% and $21.1 \%$, respectively) [46]. S. Muraki et al. (2012) also reported the incidence of radiological knee OA grade 3 or higher according to the Kellgren/Lawrence classification $(\mathrm{K} / \mathrm{L})$ in Japanese women being $13.9 \%$, which is 1.7 times higher than in men ( $8.4 \%$, OR $1.3495 \%$ CI 1.15-1.58) [47]. This group of researchers detected that knee pain was not only an important risk factor for the occurrence, but also for the progression of knee OA [47].

High bone mineral density (BMD) is known as an increased risk factor for $\mathrm{OA}$, with low bone mineral density being a protective factor [22, 48-49]. No data describing the influence of molecular mechanisms of BMD on the risk of developing OA could be found in modern literature [48]. K. N. Linde et al. (2017) reported the level of P1NP (N-terminal propeptide procollagen type 1) as a marker of bone metabolism, being significantly higher in patients with knee Kellgren/Lawrence grade IV OA than in patients with Kellgren/Lawrence grade III OA ( $45.9 \mathrm{mg} / \mathrm{l}$ and $41.9 \mathrm{mg} / \mathrm{L}$, respectively, $\mathrm{p}=0.03$ ) [50].

Osteoarthritis is a comorbid disease often combined with cardiovascular pathology, obesity, diabetes mellitus, osteoporosis, etc. [51, 52]. H.S. Kim et al. (2016) reported the prevalence of knee OA in patients with diabetes mellitus being 2.4 times higher than in patients without diabetes, adjusted for age and gender (OR $1.1995 \%$ CI 1.00-1.41; p = 0.04) [53]. F. Eymard et al. (2015) explored the influence of metabolic factors (obesity, diabetes, hypertension and dyslipidemia) on the rate of progression of knee OA and found that the width of the articular space was significantly less in patients with knee OA without type 2 diabetes than in patients with diabetes mellitus $(p=0.018)$ [52]. Type 2 diabetes mellitus in patients with knee OA joint can be considered a risk factor for the disease [25, 54]. Niu et al. (2017) detected neither metabolic syndrome nor its components being associated with radiographic and symptomatic knee OA with no statistical significance after adjustment for body mass [55].

Obesity and excessive body weight have been associated with the development and progression of knee OA [10, 40, 56-58]. Jiang et al. (2012) reported a direct relationship between obesity and the risk of $\mathrm{OA}$ in patients with knee OA with the relationship being significantly stronger in women than in men [59]. The authors found that an increase in body mass index by $5 \mathrm{~kg} / \mathrm{m} 2$ increases the risk of knee
OA by $35 \%$ (OR $1.3595 \% \mathrm{Cl} 1.21-1.51$ ) [59]. Weight loss is recognized as an effective measure for the prevention and treatment of gonarthrosis [60]. Several studies and meta-analyses of the relationship between weight loss and clinical outcomes of OA demonstrate the important role of diet therapy as a major factor in the prevention of knee OA [61-62]. S. P. Messier et al. (2013) reported a $9.5 \%$ reduction in body weight induced by diet after 18 months among overweight and obese adults, and participants in the diet + exercise groups had a significantly lower level of pain than those in the exercise group [61]. Overweight and obesity are risk factors for knee OA and for the progression of the disease [40, 62-64]. Arthroscopic evidence indicates to the negative role of synovial inflammation in the progression of cartilage degradation in gonarthrosis [65]. D.T. Felson et al. (2016) reported synovitis as an independent cause of $\mathrm{OA}$ in the review of 239 patients with knee OA and 731 controls (OR $1.195 \% \mathrm{Cl} 1.0-1.2, \mathrm{p}=0.02$ ) [66].

Vitamins and other micronutrients are involved in the pathogenesis of OA with vitamin D deficiency being a risk factor fo knee OA [9, 67-69]. Higher circulating serum levels of $25(\mathrm{OH}) \mathrm{D}$ is associated with less cartilage loss in the knee joint [70], and reduced vitamin $\mathrm{D}$ intake and low serum vitamin $\mathrm{D}$ levels are associated with a higher risk of progression of gonarthrosis [71]. Race differences in experimental pain are shown to be mediated by differences in the vitamin D level. T. L. Glover. et al. (2012) reported vitamin $\mathrm{D}$ deficiency as a risk factor for increased knee OA pain in black Americans [72]. There is evidence of vitamin $\mathrm{K}$ 's role in regulating skeletal mineralization [19, 73]. In the longitudinal study, D. Misra et al. (2013) reported subclinical vitamin $\mathrm{K}$ deficiency being associated with increased risk of developing radiographic knee OA (OR 1.56; $95 \%$ CI 1.08-2.25) [73].

There are controversies regarding prevalence of knee OA in different ethnic groups. African Americans had slightly higher prevalence of radiographic knee OA defined as Kellgren-Lawrence radiographic grades 3 and 4 compared to Caucasians [74]. B.R. Deshpande et al. (2016) estimated that in the United States in 2007-08, 13.7 million had symptomatic knee OA, with 10.4 million persons among non-Hispanic whites and 3.4 million persons among non-Hispanic blacks and Hispanics and other racial/ethnic minorities [4]. Y. Cruz-Almeida et al. (2014) detected that African American subjects with knee OA displayed increased pain sensitivity when compared to non-Hispanic white subjects with knee OA [75]. 
Genetic influences are mostly revealed in generalized OA. Assessment of hip and knee joints in 992 monozygotic and dizygotic femaletwinparticipants from the TwinsUK Registry showed the contribution of hereditary factors to the development of knee OA that accounted for $37 \%$ [76]. S.G. Skousgaard et al. explored sex differences in risk and heritability estimates on primary knee osteoarthritis leading to total knee arthroplasty and found $18 \%$ of the variation being attributable to genetic factors and $82 \%$ of the variation being attributable to common and unique environmental factors [77].

Muscle weakness is known to be associated with an increased risk of developing knee OA [18, 78-79]. S. Muraki reported quadriceps muscle weakness being significantly associated with knee pain in knee OA [80]. The systematic review and meta-analysis conducted by B.E. Oiestad et al. (2015) showed that knee extensor muscle weakness was associated with an increased risk of developing knee OA in both men and women [81].

Local risk factors for knee OA include increased physical activity. Regular moderate physical activity has well-known effects on lower-limb OA, decreasing pain and improving function. Y. Wang et al. reported increasing levels of total physical activity being positively associated with the risk of primary knee replacement due to OA [82]. C. Gay C. et al. (2018) reviewed interviews of 548 people with knee OA with $42.6 \%$ of patients reported high, $38.6 \%$ moderate, and $18.8 \%$ low physical activity level [83]. Variables significantly related to inactive or minimally active PA levels were BMI $(p=0.03)$ and sex $(p=0.0008)$, and biomedical barriers, related to self-efficacy $(p=0.0118)$ [83]. The study performed by J. Gholami did not show any significant association between knee
OA and daily occupational and non-occupational activities like squatting, climbing, kneeling, lifting and carrying weights [84].

Knee OA was also shown to be associated with occupational factor and sport loads. Occupational activity associated with performing repetitive movements can lead to overloading the joints and fatigue muscles and increase the risk of developing $\mathrm{OA}$ in the joints [25]. In this case, the risk of OA is doubled compared to people whose activities do not require physical activity and repetition of movements [85]. Exposure to physical work activities can aggravate knee OA. There is evidence that work performed on the knees when the joint is bent for a long time increases the risk of developing knee OA $[19,86]$. Increased risk of developing knee OA was found among those who work with the knee joint being bent for a long time $[19,86]$.

A higher incidence of knee OA was reported in high-impact sports (football, baseball, runners) players due to greater stress on the joint, a wrong movement during performance resulting in injury to articular cartilage, subchondral bone, collateral ligament and meniscus [25] that can often cause secondary or posttraumatic OA. K.A. Timmins et al. (2017) performed a systematic review and determined no significant association between running and the development of knee OA [88]. S. Mat et al. (2015) reported strength training and aerobics exercises improving balance and falls risk in older individuals with knee OA [89]. Traumatic injuries play a significant role in the etiopathogenesis of knee OA but the condition cannot be unequivocally recognized as a posttraumatic disease [25]. S. Muraki et al. (2012) reported a previous knee injury being a risk factor for knee pain but not for radiographic knee OA [90].

\section{CONCLUSION}

The literature review demonstrated a diversity of molecular mechanisms in the etiology and pathogenesis of knee OA. First, mechanisms associated with impaired cartilage metabolism, inflammation, changes in the subchondral bone, and pathological processes in the synovium were shown to play a significant role in the development of knee OA. Second, knee OA appeared to be a heterogeneous disease with a range of risk factors including local (history of knee injury, muscle weakness, joint malalignment, surgical interventions on the joint, increased physical activity) and systemic (older age, female gender, high height, overweight and obesity, hereditary predisposition, bone mineral density, vitamin $\mathrm{D}$ deficiency, ethnicity) aspects. The risk factors are essential for genetic and epidemiological studies of knee OA.

Declaration of Conflicting Interests The authors declared no potential conflicts of interest with respect to the authorship and/or publication of this article.

Funding The authors received no financial support for the research and/or authorship of this article.

\section{REFERENCES}

1. Nasonov E.L., Nasonova V.A., eds. Revmatologiia. Natsionalnoe rukovodstvo [Reheumatology. National manual]. M., GEOTAR-Media, 2010. 714 p. (in Russian)

2. Matveev R.P., Bragina S.V. Osteoartroz kolennogo sustava: problemy i sotsialnaia znachimost [Osteoarthrosis of the knee: problems and social significance]. Ekologiia Cheloveka, 2012, no. 9, pp. 53-62. (in Russian) 
3. World Health Organization, Department of Chronic Diseases and Health Promotion. Chronic rheumatic conditions. Geneva, World Health Organization. Available at: http://www.who.int/chp/topics/rheumatic/en/ (дата обращения: 10.01.2010).

4. Deshpande B.R., Katz J.N., Solomon D.H., Yelin E.H., Hunter D.J., Messier S.P., Suter L.G., Losina E. Number of Persons with Symptomatic Knee Osteoarthritis in the US: Impact of Race and Ethnicity, Age, Sex, and Obesity. Arthritis Care Res. (Hoboken), 2016, vol. 68, no. 12, pp.1743-1750. DOI: $10.1002 /$ acr.22897

5. Balabanova R.M., Erdes Sh.F. Rasprostranennost revmaticheskikh zabolevanii v Rossii v 2012-2013 gg. [Prevalence of rheumatological diseases in Russia in 2012-2013]. Nauchno-prakticheskaia Revmatologiia, 2015, vol. 53, no. 2, pp. 120-124. (in Russian)

6. Daigle M.E., Weinstein A.M., Katz J.N., Losina E. The cost-effectiveness of total joint arthroplasty: a systematic review of published literature. Best Pract. Res. Clin. Rheumatol., 2012, vol. 26, no. 5, pp. 649-658. DOI: 10.1016/j.berh.2012.07.013

7. Weinstein A.M., Rome B.N., Reichmann W.M., Collins J.E., Burbine S.A., Thornhill T.S., Wright J., Katz J.N., Losina E. Estimating the burden of total knee replacement in the United States. J. Bone Joint Surg. Am., 2013, vol. 95, no. 5, pp. 385-392. DOI: 10.2106/JBJS.L.00206

8. Kornilov N.N., Kuliaba T.A., Fil A.S., Muraveva Iu.V. Dannye Registra endoprotezirovaniia kolennogo sustava RNIITO im. R.R. Vredena za 2011-2013 gody [Data from the Register of the knee arthroplasty of Russian Vreden Scientific Research Institute of Traumatology and Orthopaedics /RVSRITO/ for 2011-2013]. Travmatologiia i Ortopediia Rossii, 2015, no. 1 (75), pp. 136-151. (in Russian)

9. Bazhenov A.N. Vitamin D i osteoartroz [Vitamin D and osteoarthrosis]. Transliatsionnaia Meditsina, 2016, vol. 3, no. 1, pp. 39-42. (in Russian)

10. Lespasio M.J., Piuzzi N.S., Husni M.E., Muschler G.F., Guarino A., Mont M.A. Knee Osteoarthritis: A Primer. Perm. J., 2017 , vol. 21 , pp. 16-183. DOI:10.7812/TPP/16-183

11. Geyer M., Schönfeld C. Novel Insights into the Pathogenesis of Osteoarthritis. Curr. Rheumatol. Rev., 2018, vol.14, no. 2, pp. 98-107. DOI:10.217 4/1573397113666170807122312

12. Shostak N.A. Osteoartroz: aktualnye voprosy diagnostiki i lecheniia [Osteoarthrosis: actual problems of diagnosis and treatment]. Russkii Meditsinskii Zhurnal. Meditsinskoe Obozrenie, 2014, vol. 22, no. 4, pp. 278-281. (in Russian)

13. Glyn-Jones S., Palmer A.J., Agricola R., Price A.J., Vincent T.L., Weinans H., Carr A.J. Osteoarthritis. Lancet, 2015 , vol. 386, no. 9991 , pp. $376-387$. DOI:10.1016/S0140-6736(14)60802-3

14. Snochowska A., Szmigielska P., Brzeziańska-Lasota E., Tomaszewski W. Genetic and Epigenetic Interactions in the Etiopathogenesis of Osteoarthritis. Selected Molecular Factors in OA Etiopathogenesis. Ortop. Traumatol. Rehabil., 2017, vol. 19, no. 3, pp. 227-237. DOI:10.5604/15093492.1240791

15. Andriacchi T.P., Favre J., Erhart-Hledik J.C., Chu C.R. A systems view of risk factors for knee osteoarthritis reveals insights into the pathogenesis of the disease. Ann. Biomed. Eng., 2015, vol. 43, no. 2, pp. 376-387. DOI:10.1007/s10439-014-1117-2

16. Diadyk A.I., Malovichko I.S., Zdikhovskaia I.I., Shpilevaia N.I. Osteoartroz: voprosy patogeneza, diagnostiki, lechebnoi taktiki [Problems of pathogenesis, diagnosis, treatment tactics]. Novosti Meditsiny i Farmatsii, 2012, no. 1-2 (399-400), pp. 23-29. (in Russian)

17. Lisitsina E.M., Lisitsin M.P., Zaremuk A.M. Sovremennyi podkhod k patogenezu, diagnostike i lecheniiu osteoartroza kolennogo sustava [Current approach to pathogenesis, diagnosis, and treatment of the knee osteoarthrosis]. Endoskopicheskaia Khirurgiia, 2016, vol. 22, no. 6, pp. 57-67. (in Russian) DOI: 10.17116/endoskop201622657-67

18. Jones G. What's new in osteoarthritis pathogenesis? Intern. Med. J., 2016, vol. 46, no. 2, pp. 229-236. DOI: 10.1111/imj.12763

19. Mazurov V.I., Trofimova A.S., Trofimov E.A. Faktory riska i nekotorye aspekty patogeneza osteoartrita [Risk factors and some aspects of osteoarthritis pathogenesis]. Vestnik Severo-Zapadnogo Gosudarstvennogo Meditsinskogo Universiteta im. I.I. Mechnikova, 2016, vol. 8, no. 2, pp. 116-124. (in Russian)

20. Zaitseva E.M., Alekseeva L.I., Nasonov E.L. Patogenez osteoartroza i obosnovanie primeneniia strontsiia ranelata [Pathogenesis of osteoarthrosis and rationale for strontium ranelate use]. Nauchno-Prakticheskaia Revmatologiia, 2013, vol. 51, no. 6, pp. 696-702. (in Russian)

21. Samoilov V.V., Miromanov A.M., Samoilova S.I. Znachenie tsitokinov v patogeneze osteoartroza [Significance of cytokines in osteoarthrosis pathogenesis]. Zabaikalskii Meditsinskii Vestnik, 2014, no. 2, pp. 119-125. (in Russian)

22. Ratneswaran A., Rockel J.S., Kapoor M. Understanding osteoarthritis pathogenesis: a multiomics system-based approach. Curr. Opin. Rheumatol., 2020. vol. 32, no 1. pp.80-91. DOI:10.1097/BOR.0000000000000680

23. Vakulenko O.Iu., Zhiliaev E.V. Osteoartroz: sovremennye podkhody k lecheniiu [Osteoarthrosis: current approaches to treatment]. Russkii Meditsinskii Zhurnal, 2016, vol. 24, no. 22, pp. 1494-1498. (in Russian)

24. Nguyen L.T., Sharma A.R., Chakraborty C., Saibaba B., Ahn M.E., Lee S.S. Review of Prospects of Biological Fluid Biomarkers in Osteoarthritis. Int. J. Mol. Sci., 2017, vol. 18, no. 3, pp. 601. DOI:10.3390/ijms18030601

25. Musumeci G., Aiello F.C., Szychlinska M.A., Di Rosa M., Castrogiovanni P., Mobasheri A. Osteoarthritis in the XXIst Century: risk factors and behaviours that influence disease onset and progression. Int. J. Mol. Sci., 2015, vol. 16, no. 3, pp. 6093-6112. DOI:10.3390/ijms16036093

26. Shukurova S.M., Khamroeva Z.D., Shodiev B.R., Karimova G.N. Osteoartroz kak vazhnaia problema geriatrii [Osteoarthrosis as an important problem of geriatrics]. Vestnik Avitsenny, 2016, no. 1 (66), pp. 137-143. (in Russian)

27. Jacobs C.A, Vranceanu A.M., Thompson K.L., Lattermann C. Rapid Progression of Knee Pain and Osteoarthritis Biomarkers Greatest for Patients with Combined Obesity and Depression: Data from the Osteoarthritis Initiative. Cartilage, 2020. vol. 11, no 1, pp. 38-46. DOI:10.1177/1947603518777577

28. Swift A. Osteoarthritis 1: Physiology, risk factors and causes of pain. Nurs. Times, 2012, vol. 108, no. 7, pp. 12-15.

29. Dubikov A.I. Osteoartroz: staraia bolezn, novye podkhody [Osteoarthrosis: old disease, new approaches]. Sovremennaia Revmatologiia, 2013, vol. 7, no. 2, pp. 82-86. (in Russian)

30. Aganov D.S., Tyrenko V.V., Tsygan E.N., Toporkov M.M., Bologov S.G. Rol tsitokinovoi sistemy RANKL/RANK/OPG v reguliatsii mineralnogo obmena kostnoi tkani [The role of RANKL/RANK/OPG cytokine system in the regulation of bone tissue mineral metabolism]. Geny $i$ Kletki, 2014, no. 4, pp. 50-52. (in Russian)

31. Siniachenko O.V., Ermolova M.V., Geiko I.A., Taktashov G.S., Iutovets T.S. Rol kostnogo metabolizma v patogeneze gonartroza [The role of bone metabolism in gonarthrosis pathogenesis]. Travma, 2016, vol. 17, no. 1, pp. 67-70. (in Russian)

32. Alizai H., Roemer F.W., Hayashi D., Crema M.D., Felson D.T., Guermazi A. An update on risk factors for cartilage loss in knee osteoarthritis assessed using MRI-based semiquantitative grading methods. Eur. Radiol., 2015, vol. 25, no. 3, pp.883-893. DOI:10.1007/s00330-014-3464-7

33. Lyu S.R., Chiang C.Y., Cherng J.Y., Huang Y.C., Li C.H., Lin Y.J., Chang C.M., Chau L.K. Role of medial abrasion phenomenon in the pathogenesis of knee osteoarthritis. Med. Hypotheses, 2015, vol. 85, no. 2, pp. 207-211. DOI: 10.1016/j.mehy.2015.04.028

34. Chundru R., Baum T., Nardo L., Nevitt M.C., Lynch J., McCulloch C.E., Link T.M. Focal knee lesions in knee pairs of asymptomatic and symptomatic subjects with OA risk factors - data from the Osteoarthritis Initiative. Eur. J. Radiol., 2013, vol. 82, no. 8, pp. e367-e373. DOI: 10.1016/j.ejrad.2013.02.038

35. Heijink A., Gomoll A.H., Madry H., Drobnič M., Filardo G., Espregueira-Mendes J., Van Dijk C.N. Biomechanical considerations in the pathogenesis of osteoarthritis of the knee. Knee Surg. Sports Traumatol. Arthrosc., 2012, vol. 20, no. 3, pp. 423-435. DOI:10.1007/s00167-011-1818-0

36. Hussain S.M., Neilly D.W., Baliga S., Patil S., Meek R. Knee osteoarthritis: a review of management options. Scott. Med. J., 2016, vol. 61, no. 1, pp. 7-16. DOI: $10.1177 / 0036933015619588$

37. Blagojevic M., Jinks C., Jeffery A., Jordan K.P. Risk factors for onset of osteoarthritis of the knee in older adults: a systematic review and metaanalysis. Osteoarthritis Cartilage, 2010, vol. 18, no. 1, pp. 24-33. DOI: 10.1016/j.joca.2009.08.010

38. Heidari B. Knee osteoarthritis prevalence, risk factors, pathogenesis and features: Part I. Caspian J. Intern. Med., 2011, vol. 2, no. 2, pp. 205-212.

39. Pereira D., Ramos E., Branco J. Osteoarthritis. Acta Med. Port., 2015, vol. 28, no. 1, pp. 99-106. DOI:106. 10.20344/amp.5477

40. Kashevarova N.G., Alekseeva L.I. Faktory riska progressirovaniia osteoartroza kolennykh sustavov [Risk factors for progression of the knee osteoarthrosis]. Nauchno-Prakticheskaia Revmatologiia, 2014, vol. 52, no. 5, pp. 553-561. (in Russian). DOI: 10.14412/1995-4484-2014-553-561

41. Kavalerskii G., Smetanin S., Lychagin A., Moisov A. Faktory riska razvitiia osteoartroza kolennogo sustava [Risk factors for the knee osteoarthrosis development]. Vrach, 2017, no. 3, pp. 22-24. (in Russian)

42. Haq S.A., Davatchi F. Osteoarthritis of the knees in the COPCORD world. Int. J. Rheum. Dis., 2011, vol. 14, no. 2, pp. 122-129. DOI:10.1111/ j.1756-185X.2011.01615.x 
43. Panikar V.I., Shcherban E.A., Pavlova I.A. Kompleksnaja geriatricheskaja otsenka osteoartroza kolennyh sustavov v starcheskom vozraste [Complex geriatric assessment of osteoarthrosis of knee joints in the senior age]. Research Results in Biomedicine, 2019, vol. 5, no 1, pp. 131-139. (in Russian)]. DOI: 10.18413/2313-8955-2019-5-1-0-10

44. Prieto-Alhambra D., Judge A., Javaid M.K., Cooper C., Diez-Perez A., Arden N.K. Incidence and risk factors for clinically diagnosed knee, hip and hand osteoarthritis: influences of age, gender and osteoarthritis affecting other joints. Ann. Rheum. Dis., 2014, vol. 73, no. 9, pp. 1659-1664. DOI:10.1136/annrheumdis-2013-203355

45. Povorozniuk V.V., Grigoreva N.V. Osteoartroz u zhenshchin v postmenopauze: faktory riska i sviaz s kostnoi tkaniu [Osteoarthrosis in postmenopausal women: risk factors and relationship to bone tissue]. Reproduktivnaia Endokrinologiia, 2012, no. 6 (8), pp. 64-71. (in Russian)

46. Lee S., Kim S.J. Prevalence of knee osteoarthritis, risk factors, and quality of life: The Fifth Korean National Health and Nutrition Examination Survey. Int. J. Rheum. Dis., 2017, vol. 20, no. 7, pp. 809-817. DOI:10.1111/1756-185X.12795

47. Muraki S., Akune T., Oka H., Ishimoto Y., Nagata K., Yoshida M., Tokimura F., Nakamura K., Kawaguchi H., Yoshimura N. Incidence and risk factors for radiographic knee osteoarthritis and knee pain in Japanese men and women: a longitudinal population-based cohort study. Arthritis Rheum., 2012, vol. 64, no. 5, pp. 1447-1456. DOI:10.1002/art.33508

48. Barbour K.E., Murphy L.B., Helmick C.G., Hootman J.M., Renner J.B., Jordan J.M. Bone Mineral Density and the Risk of Hip and Knee Osteoarthritis: The Johnston County Osteoarthritis Project. Arthritis Care Res. (Hoboken), 2017, vol. 69, no. 12, pp. 1863-1870. DOI:10.1002/ acr.23211

49. Funck-Brentano T., Cohen-Solal M. Subchondral bone and osteoarthritis. Curr. Opin. Rheumatol., 2015, vol. 27, no. 4, pp. 420-426. DOI:10.1097/ BOR.0000000000000181

50. Linde K.N., Puhakka K.B., Langdahl B.L., Søballe K., Krog-Mikkelsen I., Madsen F., Stilling M. Bone Mineral Density is Lower in Patients with Severe Knee Osteoarthritis and Attrition. Calcif. Tissue Int., 2017, vol. 101, no. 6, pp. 593-601. DOI:10.1007/s00223-017-0315-y

51. Golovach I.Iu. Osteoartrit: sovremennye fundamentalnye i prikladnye aspekty patogeneza zabolevaniia [Osteoarthritis: current fundamental and applied aspects of the disease pathogenesis]. Bol. Sustavy. Pozvonochnik, 2014, no. 3 (15), pp. 54-58. (in Russian)

52. Eymard F., Parsons C., Edwards M.H., Petit-Dop F., Reginster J.Y., Bruyère O., Richette P., Cooper C., Chevalier X. Diabetes is a risk factor for knee osteoarthritis progression. Osteoarthritis Cartilage, 2015, vol. 23, no. 6, pp. 851-859. DOI: 10.1016/j.joca.2015.01.013

53. Kim H.S., Shin J.S., Lee J., Lee Y.J., Kim M.R., Bae Y.H., Park K.B., Lee E.J., Kim J.H., Ha I.H. Association between Knee Osteoarthritis, Cardiovascular Risk Factors, and the Framingham Risk Score in South Koreans: A Cross-Sectional Study. PLoS One, 2016, vol. 11, no. 10, pp. e0165325. DOI: 10.1371/journal.pone.0165325.

54. Berenbaum F. Diabetes-induced osteoarthritis: from a new paradigm to a new phenotype. Ann. Rheum. Dis., 2011, vol. 70, no. 8, pp. $1354-1356$. DOI: $10.1136 /$ ard.2010.146399.

55. Niu J., Clancy M., Aliabadi P., Vasan R., Felson D.T. Metabolic Syndrome, Its Components, and Knee Osteoarthritis: The Framingham Osteoarthritis Study. Arthritis Rheumatol., 2017, vol. 69, no. 6, pp. 1194-1203. DOI: 10.1002/art.40087

56. Losina E., Walensky R.P., Reichmann W.M., Holt H.L., Gerlovin H., Solomon D.H., Jordan J.M., Hunter D.J., Suter L.G., Weinstein A.M., Paltiel A.D., Katz J.N. Impact of obesity and knee osteoarthritis on morbidity and mortality in older Americans. Ann. Intern. Med., 2011, vol. 154, no. 4, pp. 217-226. DOI: $10.7326 / 0003-4819-154-4-201102150-00001$

57. Kulkarni K., Karssiens T., Kumar V., Pandit H. Obesity and osteoarthritis. Maturitas, 2016, vol. 89, pp. 22-28. DOI: 10.1016/j.maturitas.2016.04.006

58. Belluzzi E., El Hadi H., Granzotto M., Rossato M., Ramonda R., Macchi V., De Caro R., Vettor R., Favero M. Systemic and Local Adipose Tissue in Knee Osteoarthritis. J. Cell. Physiol., 2017, vol. 232, no. 8, pp. 1971-1978. DOI:10.1002/jcp.25716

59. Jiang L., Tian W., Wang Y., Rong J., Bao C., Liu Y., Zhao Y., Wang C. Body mass index and susceptibility to knee osteoarthritis: a systematic review and meta-analysis. Joint Bone Spine, 2012, vol. 79, no. 3, pp. 291-297. DOI: 10.1016/j.jbspin.2011.05.015

60. Silverwood V., Blagojevic-Bucknall M., Jinks C., Jordan J.L., Protheroe J., Jordan K.P. Current evidence on risk factors for knee osteoarthritis in older adults: a systematic review and meta-analysis. Osteoarthritis Cartilage, 2015, vol. 23, no. 4, pp. 507-515. DOI: 10.1016/j.joca.2014.11.019

61. Messier S.P., Mihalko S.L., Legault C., Miller G.D., Nicklas B.J., DeVita P., Beavers D.P., Hunter D.J., Lyles M.F., Eckstein F., Williamson J.D., Carr J.J., Guermazi A., Loeser R.F. Effects of intensive diet and exercise on knee joint loads, inflammation, and clinical outcomes among overweight and obese adults with knee osteoarthritis: the IDEA randomized clinical trial. JAMA, 2013, vol. 310, no. 12, pp. 1263-1273. DOI:10.1001/ jama.2013.277669

62. Wluka A.E., Lombard C.B., Cicuttini F.M. Tackling obesity in knee osteoarthritis. Nat. Rev. Rheumatol., 2013, vol. 9, no. 4, pp. 225-235. DOI: https: 10.1038/nrrheum.2012.224

63. Apold H., Meyer H.E., Nordsletten L., Furnes O., Baste V., Flugsrud G.B. Risk factors for knee replacement due to primary osteoarthritis, a population based, prospective cohort study of 315,495 individuals. BMC Musculoskelet. Disord., 2014, vol. 15, pp. 217. DOI:10.1186/1471-2474-15-217

64. Bastick A.N., Belo J.N., Runhaar J., Bierma-Zeinstra S.M. What Are the Prognostic Factors for Radiographic Progression of Knee Osteoarthritis? A Meta-analysis. Clin. Orthop. Relat Res., 2015, vol. 473, no. 9, pp. 2969-89. DOI:10.1007/s11999-015-4349-z

65. Atukorala I., Kwoh C.K., Guermazi A., Roemer F.W., Boudreau R.M., Hannon M.J., Hunter D.J. Synovitis in knee osteoarthritis: a precursor of disease? Ann. Rheum. Dis., 2016, vol. 75, no. 2, pp.390-395. DOI:10.1136/annrheumdis-2014-205894

66. Felson D.T., Niu J., Neogi T., Goggins J., Nevitt M.C., Roemer F., Torner J., Lewis C.E., Guermazi A.; MOST Investigators Group. Synovitis and the risk of knee osteoarthritis: the MOST Study. Osteoarthritis Cartilage, 2016, vol. 24, no. 3, pp. 458-464. DOI: 10.1016/j.joca.2015.09.013

67. Wang X., Hunter D., Xu J., Ding C. Metabolic triggered inflammation in osteoarthritis. Osteoarthritis Cartilage, 2015, vol. 23, no. 1, pp. 22-30. DOI:10.1016/j.joca.2014.10.002

68. Barker T., Henriksen V.T., Rogers V.E., Aguirre D., Trawick R.H., Lynn Rasmussen G., Momberger N.G. Vitamin D deficiency associates with $\gamma$-tocopherol and quadriceps weakness but not inflammatory cytokines in subjects with knee osteoarthritis. Redox. Biol., 2014, vol. 2, pp. 466-474. DOI:10.1016/j.redox.2014.01.024

69. Sanghi D., Mishra A., Sharma A.C., Raj S., Mishra R., Kumari R., Natu S.M., Agarwal S., Srivastava R.N. Elucidation of dietary risk factors in osteoarthritis knee - a case-control study. J. Am. Coll. Nutr., 2015, vol. 34, no. 1, pp. 15-20. DOI:10.1080/07315724.2013.875439

70. Sanghi D., Mishra A., Sharma A.C., Raj S., Mishra R., Kumari R., Natu S.M., Agarwal S., Srivastava R.N. Vitamin D supplementation in the management of knee osteoarthritis: study protocol for a randomized controlled trial. Trials, 2012, vol. 13, pp. 131. DOI: 10.1186/1745-6215-13-131

71. Zhang F.F., Driban J.B., Lo G.H., Price L.L., Booth S., Eaton C.B., Lu B., Nevitt M., Jackson B., Garganta C., Hochberg M.C., Kwoh K., McAlindon T.E. Vitamin D deficiency is associated with progression of knee osteoarthritis. J. Nutr., 2014, vol.144, no. 12, pp. 2002-2008. DOI:10.3945/ jn.114.193227

72. Glover T.L., Goodin B.R., Horgas A.L., Kindler L.L., King C.D., Sibille K.T., Peloquin C.A., Riley J.L. 3rd, Staud R., Bradley L.A., Fillingim R.B. Vitamin D, race, and experimental pain sensitivity in older adults with knee osteoarthritis. Arthritis. Rheum., 2012, vol. 64, no. 12, pp. $3926-3935$. DOI: $10.1002 /$ art.37687

73. Misra D., Booth S.L., Tolstykh I., Felson D.T., Nevitt M.C., Lewis C.E., Torner J., Neogi T. Vitamin K deficiency is associated with incident knee osteoarthritis. Am. J. Med., 2013, vol. 126, no. 3, pp. 243-248. DOI: 10.1016/j.amjmed.2012.10.011

74. Jordan J.M., Helmick C.G., Renner J.B., Luta G., Dragomir A.D., Woodard J., Fang F., Schwartz T.A., Abbate L.M., Callahan L.F., Kalsbeek W.D., Hochberg M.C. Prevalence of knee symptoms and radiographic and symptomatic knee osteoarthritis in African Americans and Caucasians: the Johnston County Osteoarthritis Project. J. Rheumatol., 2007, vol. 34, no. 1, pp. 172-180.

75. Cruz-Almeida Y., Sibille K.T., Goodin B.R., Petrov M.E., Bartley E.J., Riley J.L. 3rd, King C.D., Glover T.L., Sotolongo A., Herbert M.S., Schmidt J.K., Fessler B.J., Staud R., Redden D., Bradley L.A., Fillingim R.B. Racial and ethnic differences in older adults with knee osteoarthritis. Arthritis Rheumatol., 2014, vol. 66, no. 7, pp. 1800-1810. DOI:10.1002/art.38620

76. MacGregor A.J., Li Q., Spector T.D., Williams F.M. The genetic influence on radiographic osteoarthritis is site specific at the hand, hip and knee. Rheumatology (Oxford), 2009, vol. 48, no. 3, pp. 277-280. DOI: 10.1093/rheumatology/ken475 
77. Skousgaard S.G., Skytthe A., Möller S., Overgaard S., Brandt L.P. Sex differences in risk and heritability estimates on primary knee osteoarthritis leading to total knee arthroplasty: a nationwide population based follow up study in Danish twins. Arthritis Res. Ther., 2016 , vol. 18, pp. 46. DOI: 10.1186/s13075-016-0939-8

78. Heidari B., Javadian Y., Babaei M., Yousef-Ghahari B. Restorative Effect of Vitamin D Deficiency on Knee Pain and Quadriceps Muscle Strength in Knee Osteoarthritis. Acta Med. Iran, 2015, vol. 53, no. 8, pp. 466-470.

79. Segal N., Davis M.D., Mikesky A.E. Efficacy of Blood Flow-Restricted Low-Load Resistance Training for Quadriceps Strengthening in Men at Risk of Symptomatic Knee Osteoarthritis. Geriatr. Orthop. Surg. Rehabil., 2015, vol. 6, no. 3, pp. 160-167. DOI:10.1177/2151458515583088

80. Muraki S., Akune T., Teraguchi M., Kagotani R., Asai Y., Yoshida M., Tokimura F., Tanaka S., Oka H., Kawaguchi H., Nakamura K., Yoshimura N. Quadriceps muscle strength, radiographic knee osteoarthritis and knee pain: the ROAD study. BMC Musculoskelet. Disord., 2015 , vol. 16, pp. 305. DOI: $10.1186 / \mathrm{s} 12891-015-0737-5$

81. Øiestad B.E., Juhl C.B., Eitzen I., Thorlund J.B. Knee extensor muscle weakness is a risk factor for development of knee osteoarthritis. A systematic review and meta-analysis. Osteoarthritis Cartilage, 2015, vol. 23, no. 2, pp. 171-177. DOI: 10.1016/j.joca.2014.10.008

82. Wang Y., Simpson J.A., Wluka A.E., Teichtahl A.J., English D.R., Giles G.G., Graves S., Cicuttini F.M. Is physical activity a risk factor for primary knee or hip replacement due to osteoarthritis? A prospective cohort study. J. Rheumatol., 2011, vol. 38, no. 2, pp. 350-357. DOI:10.3899/ jrheum.091138

83. Gay C., Guiguet-Auclair C., Mourgues C., Gerbaud L., Coudeyre E. Physical activity level and association with behavioral factors in knee osteoarthritis. Ann. Phys. Rehabil. Med., 2019, vol. 62, no. 1, pp. 14-20. DOI: 10.1016/j.rehab.2018.09.005

84. Gholami J., Mansournia M.A., Davatchi F., Mohammad K., Hosseini H., Majdzadeh R. Are daily physical activities risk factors for knee osteoarthritis? Int. J. Rheum. Dis., 2016, vol. 19, no. 3, pp. 241-247. DOI:10.1111/1756-185X.12604

85. Messier S.P., Legault C., Mihalko S., Miller G.D., Loeser R.F., DeVita P., Lyles M., Eckstein F., Hunter D.J., Williamson J.D., Nicklas B.J. The Intensive Diet and Exercise for Arthritis (IDEA) trial: Design and rationale. BMC Musculoskelet. Disord., 2009, vol. 10, pp. 93. DOI:10.1186/14712474-10-93

86. Palmer K.T. Occupational activities and osteoarthritis of the knee. Br. Med. Bull., 2012, vol. 102, pp. 147-170. DOI:10.1093/bmb/lds012

87. Vannini F., Spalding T., Andriolo L., Berruto M., Denti M., Espregueira-Mendes J., Menetrey J., Peretti G.M., Seil R., Filardo G. Sport and early osteoarthritis: the role of sport in aetiology, progression and treatment of knee osteoarthritis. Knee Surg. Sports Traumatol. Arthrosc., 2016, vol. 24, no. 6, pp. 1786-1796. DOI:10.1007/s00167-016-4090-5

88. Timmins K.A., Leech R.D., Batt M.E., Edwards K.L. Running and Knee Osteoarthritis: A Systematic Review and Meta-analysis. Am. J. Sports Med., 2017, vol. 45, no. 6, pp. 1447-1457. DOI:10.1177/0363546516657531

89. Mat S., Tan M.P., Kamaruzzaman S.B., Ng C.T. Physical therapies for improving balance and reducing falls risk in osteoarthritis of the knee: a systematic review. Age Ageing, 2015, vol. 44, no. 1, pp. 16-24. DOI:10.1093/ageing/afu112

90. Muraki S., Akune T., Oka H., Ishimoto Y., Nagata K., Yoshida M., Tokimura F., Nakamura K., Kawaguchi H., Yoshimura N. Incidence and risk factors for radiographic knee osteoarthritis and knee pain in Japanese men and women: a longitudinal population-based cohort study. Arthritis Rheum. 2012, vol. 64, no 5, pp. 1447-1456. DOI: 10.1002/art.33508

Received: 20.02 .2020

\section{Information about the authors:}

1. Vitaly B. Novakov,

Belgorod State National Research University, Belgorod, Russian Federation,

Email: v.novakov@bk.ru

2. Olga N. Novakova, Ph.D. of Biological Sciences,

Belgorod State National Research University, Belgorod, Russian Federation, Email: litovkina@bsu.edu.ru

3. Mikhail I. Churnosov, M.D., Ph.D., Professor,

Belgorod State National Research University, Belgorod, Russian Federation,

Email: churnosov@bsu.edu.ru 